\title{
Women and Human Rights at a Glance
}

\author{
Prof (Dr) Rosamma Mathew \\ M.A (History), M.A (Politics), M.E d, M.S.W \& PhD Associate Professor\& Research Guide in History \\ Kuriakose Elias College Mannanam, Kottayam
}

\begin{abstract}
Women and Human Rights at a glance' is a much debated topic in the contemporary society. Today the world has gone far ahead in its material progress. Inventions have become popularized, communities have become stabilized and people have become sophisticated. We, the citizen of the new millennium are destined to tune with the new wave of developments happening in the entire world now. It is the apt time to analyze the world from different angles. One of the chief dimensions or angles is to study women and human rights in its true perspective. This study is hypothesized that human rights are the basic and inalienable rights equally provided to all and in special it relates with women in their spheres of life. The study signifies the human rights and its influences on women. The idea of human rights is as old as the history of man kind. By virtue of being born as a human being, man is entitled to enjoy these rights. Human rights are moral claims which are inseparable and inherent in all human individuals. As these rights have become an integral part of every culture, civilization, religion and philosophical traditions, it is equally important that we should take steps to safe guard them. This article intends to familiarize us with the different areas of concern regarding human rights and to keep us aware of the danger in violating them especially with regard to women in all scenario of life.
\end{abstract}

\section{Introduction}

They call women the weaker sex and both men and women liked to hear it so far. Both of them are complimentary to each other in all aspects of life. Beyond that we can see that the advance of women has been a focus of the wok of the United Nations since its creation. The Preamble of the Charter proclaims that one of the purposes of the United Nations is to achieve international cooperation in promoting and encouraging respect for human rights and fundamental freedoms for the people irrespective of race, sex, language or religion. In the article I defines the term discrimination against women as any distinction, exclusion or restriction made on the basis of sex which has the effect or purpose of impairing or nullifying the recognition, enjoyment or exercise by women, irrespective of their marital status, on of the Charter of the United Nations sets as a basic goal to reaffirm faith in fundamental human rights, in the dignity and worth of the human person, in the equal rights of men and women a basis of equality of men and women, of human rights, and fundamental freedoms in the political, economic, social, cultural, civil or any other field ${ }^{1}$ By all means there is a simple, yet significant shift in perspective- life does not just happen to us. We all have role in the unfolding of our lives, no matter our circumstances. In this accord we can say that the United Nations Universal Declaration of Human Rights \{UDHR \} expresses the credo that all human beings are created free and equal. But not until 1995 did the United Nations declare women's rights to be human rights and bring gender issues into the global arena for the first time.

\section{Women And Education : A New Scenario}

The best means of making ones life useful and ideal is to educate himself.. For people of any kind education is the back bone of the societal life. But its denial was an important injustice .Good education is that which draws out and stimulates spiritual, intellectual and physical faculties of people .Since education is the tool to socio-economic changes its free and easy access has been the prime factor to all people. Every woman, man, youth and child has the human right to education, training, information, and to other fundamental human rights dependent upon the realization of human right to education. The human right of all persons to education is explicitly set out in the Universal Declaration of Human Rights, the International Covenants, the Convention on the Rights of the Child and other widely adhered to international human rights treaties and Declarations powerful tools that must be put to use in realizing the human right to education for all. Education can be used as a devise to empower the individual and has opened a new horizon to the formal and informal development of women in special. Its rich impart helps a lot to reshape the destiny of all. Through learning the members of the vulnerable group is able to see their own role and position in the formation and transformation of the entire community. Societal change comes from the collective transformation of the individuals within that society. Literacy allows people, particularly those who are marginalized and discriminated, to acquire a 'critical consciousness'. Empowered individuals are better equipped to question and critique societal realities and are 
aware to change their situations to the better. Rather than being merely in the world, individuals can be taught that they are actually co-creators of their reality. There is notable relation between education and social changes. According to MacIver social change takes place as a response to many types of changes that take place in the social and non -social environment ${ }^{2}$ Education can initiate social changes by bringing about a change in outlook and attitude of man and women. Women shall be provided same opportunities as to men in matters 'relating to scholarship and other study grants. Whenever we are willingly extent all kinds of support and facilities to the marginalized, we would be able to build a new society of integrated developments. Article 10 of the Indian Constitution declares that women shall be provided same conditions for careers and vocational guidance as to that of men. Here comes the significance of giving an eye and ear to Women's Human Rights.

\section{Employment Opportunities: A New Area Of Challenge}

Since human beings are encircled by different options, he has the capability to make use of the best in the society. The Article 11 provided that the authorities shall take all appropriate measures to eliminate discrimination against women in the field of employment providing the same rights, in particular: (a) the right to work; b) right to same employment opportunities; c) right to free choice of profession and employment; d) right to equal remuneration including benefits and to equal treatment in respect of work of equal value as well as equality of treatment in the evaluation of the quality of work; e) the right to social security particularly in cases of retirement, unemployment, sickness, invalidity and old age and other incapacity to work ; as well as the right to paid leave; f) right to protection of health and to safety in working conditions. There shall be no discrimination against women on grounds of marriage or maternity. ${ }^{3}$ By all these means women got a chance to become an independent person who has keep in touch with societal changes. In order to protect the people of India from violations of Human Rights, an all India Organization for Human Rights Protection is inevitable. People of India are duty bound to safeguard the Universal declaration of Human Rights adopted and proclaimed by the General Assembly of United Nations Organization in 1948.To fight all types of violations of human rights and put an end to violence oppression and atrocities on the people, to eradicate poverty, illiteracy and unemployment and wipe out the tears of all suffering peoples and bring succor to them through legal means, to resist the callous and indifferent attitude of officials towards the day to day problems of the general public, to launch a vigorous campaign against the apathetic and in human behavior of government organizations towards the public towards classes, Scheduled Castes, Scheduled Tribes, Religious minorities and women.

\section{Women's Health And Human Rights}

It is the National Academy of Women's Health Medical Education published a comprehensive definition for Women's health which reflects a multidisciplinary approach to consider Women's health. Really it is the state to facilitate the preservation of wellness and prevention of illness. It includes diagnosis, screening and management of conditions which are unique to women, are more common in women, are more serious in women and have manifestations, risk factors or interventions which are different in women . Women's health is probably influenced by genetics, biology, physiology and also her role in the society. The field of women's health has developed in response to increasing knowledge of the non reproductive differences between men and women. Women's health also recognizes the importance of the study of gender differences, recognizes multi disciplinary team approaches that includes the values and knowledge of women and their own experiences of health and illness, recognizes the diversity of women's health needs over the life circle and how these needs reflect differences in race, class, culture, ethnicity sexual preference, level of education and access to medical care and also the empowerment of women. We can see that inequalities in the social and economic status of men and women disproportionately deprive women and their children of good health. All over the world, compared to men women tend to earn less money, economically dependent, lower educational status, and have few legal rights. These kinds of disparities lead to a second rate position and considerations to them ${ }^{4}$. One of the notable points is that with the advancements in health, sanitation and medicine a number of women lived beyond their child bearing years and more children lived in adulthood.

\section{Women And Human Rights: A Paradigm Shift}

Behold her lamentations... Because I was a girl, I was killed while I was in the womb... Because I was a girl, I was not given education.... Because I was poor and pretty, I was raped and humiliated... Because I was unhealthy, I was neglected and ignored... Because I was a woman I was denied of my rights... The cries and sighs of the women echo from every nook and corner of the society. It is the voice of women from all walks of life. The real fact is that women were denied knowledge of the existence of woman's history decisively and negatively affected their intellectual, social and economic development as a group. Here we felt the need and importance of women's rights. The original contributors to woman's human rights were those who first taught women to read and thus to explore the world out side the home and immediate community. 'Vindication of the rights of women' by Mary Wollstonecraft gives beautiful descriptions about rights of women. Over the years the 
evolution of thought and activism explained and redefine the concept of women's human rights and implemented the idea that women and men are equal members of society. ${ }^{5}$ The beginning of women's education and their increase in literacy rates enable them to articulate their view of the world. Education involves the ability to receive, create and disseminate knowledge. As knowledge is power; it helps them to understand and recognize their strength, capability and aptitude in all scenario of life. The eighteenth century educated women argued for their rights and intellectual equality. They promoted expanded educational opportunities for women which became known as 'bluestockings'. Added to this the Universal Declaration of Human Rights and the UN Charter supported the phrase equal rights of men and women. A large number of international women's Organizations accepted and promulgated the legal and social freedom obtained by women from time to time to participate in the public life even at the international level. Now we have a galaxy of women political leaders, writers, social activists and the like. There is a lack of basic knowledge about human right in today world, "vast numbers of people today are still unaware of their rights as human beings. Many suffer as a result of this lack of basic knowledge of human rights especially women.

\section{Conclusion}

Women make up 50\% of the world's population, comprise.33.3\% of labour force, perform nearly $66.6 \%$ of all working hours, receive $10 \%$ of the world's income and only less than $1 \%$ of world's property (The Voice of the Working Women 1982). Women, throughout the world remain subjugated and subordinated. The cross country scenario is one of variations in the degree of subordination rather than one of gender equality. Against this Article 1 of the United Nations Universal Declaration of Human rights, stated that "All human beings are born free and equal in dignity and rights. They are endowed with reason and conscience and should act towards one another in a spirit of brother hood. Protection of Human rights act 1993 (Amended in 2006) defines human rights as rights relating to life, liberty, equality and dignity of the individual guaranteed by the constitution or embodied in the international covenants and enforced by courts in India. Man lives by dreams, has visions and is the focal point of history. The historical backgrounds have its equal influences and impact on the life of all with out any discrimination. Society has always been proud of its people in one way or another. .In this scenario, human rights with special emphasis on women provides new platform of stability, consistency and sustainability to them. As we know truth, goodness and beauty are the basic values; human rights are inseparable from these values. Human beings possess certain basic and inalienable rights which are commonly known as human rights. As human rights are the elixir of life, it could accommodate the vulnerable to the main stream of life. As a whole all the protection acts would create new platform for integrated developments and creativity of women. Above all I think in the fast moving life circle those who belong to the special group got the chance to experience the Elixir of Life otherwise called the Human Right in all dimensions of their life in the capacity as empowered women.

\section{References}

Missing Women”, British Medical Journal 304, March 1994.p.125

D' Sousa and charls, S. (1991) The Dynamics of Human Relations, St. Paul's Training School. Bombay:p.53

Sehgal Singh B.P Human Rights in India-Problem and Perspective, Deep \&Deep Publishers, New Delhi 1985 P.241

Agarwal, H.O. Human Rights, Central Law Publications Allahabad.1999 p 210

Wollstonecraft, Mary, A Vindication of Rights of Women, 1792, (ed). Carol H. Poston, New York: Norton, 1988 p.6

Richard, Elisabeth, Understanding Human Rights: An Exercise, Sage Publication. New Delhi: 2006

Marjorie Agosfn (ed) Women, Gender and Human Rights; A Global Perspective Rawat Publications,New Delhi 2003 